\title{
A confirmatory factor analysis of the knowledge, attitude and practice questionnaire towards prevention of respiratory tract infections during Hajj and Umrah
}

\author{
Mohammed Dauda Goni ${ }^{1}$, Nyi Nyi Naing ${ }^{2 *}$, Habsah Hasan ${ }^{3}$, Nadiah Wan-Arfah ${ }^{4}$, Zakuan Zainy Deris ${ }^{3}$,
} Wan Nor Arifin ${ }^{5}$, Aisha Abubakar Baaba ${ }^{6}$ and Stanley Njaka ${ }^{7}$

\begin{abstract}
Background: Respiratory tract infections are one of the common infection associated with Haij pilgrimage that is of great public health and global concern. This study is aimed at determining the factor structure of the knowledge, attitude, and practice questionnaire for the prevention of respiratory tract infections during Hajj by confirmatory factor analysis (CFA).

Methods: A multistage cluster sampling method was conducted on Malaysian Umrah pilgrims during the weekly Umrah orientation course. A total of 200 Umrah pilgrims participated in the study. The knowledge, attitude and practice (KAP) questionnaire was distributed to pilgrims at the beginning of the orientation and retrieved immediately at the end of the orientation. Data analysis was done using R version 3.5.0 after data entry into SPSS 24. The robust maximum likelihood was used for the estimation due to the multivariate normality assumption violation. A two-factor model was tested for measurement model validity and construct validity for each of the attitude and practice domains.

Results: CFA of a 25-item in total, the two-factor model yielded adequate goodness-of-fit values. The measurement model also showed good convergent and discriminant validity after model re-specification. A two-factor model was tested for measurement model validity and construct validity for each of the attitude and practice domains. The result also showed a statistically significant value $(p<0.001)$ with $x^{2}(d f)$ values of $76.8(43)$ and $121(76)$ for attitude and practice domains, respectively.
\end{abstract}

Conclusion: The KAP questionnaire was proven to have a valid measurement model and reliable constructs. It was deemed suitable for use to measure the KAP of Hajj and Umrah pilgrims towards the prevention for all respiratory tract infections.

Keywords: Respiratory tract infection, Confirmatory factor analysis, Knowledge, Attitude, Practice

\footnotetext{
* Correspondence: syedhatim@unisza.edu.my

${ }^{2}$ Faculty of Medicine, Medical Campus Universiti Sultan Zainal Abidin, 20400 Kuala Terengganu, Malaysia

Full list of author information is available at the end of the article
}

(c) The Author(s). 2020 Open Access This article is licensed under a Creative Commons Attribution 4.0 International License, which permits use, sharing, adaptation, distribution and reproduction in any medium or format, as long as you give appropriate credit to the original author(s) and the source, provide a link to the Creative Commons licence, and indicate if changes were made. The images or other third party material in this article are included in the article's Creative Commons licence, unless indicated otherwise in a credit line to the material. If material is not included in the article's Creative Commons licence and your intended use is not permitted by statutory regulation or exceeds the permitted use, you will need to obtain permission directly from the copyright holder. To view a copy of this licence, visit http://creativecommons.org/licenses/by/4.0/. The Creative Commons Public Domain Dedication waiver (http://creativecommons.org/publicdomain/zero/1.0/) applies to the data made available in this article, unless otherwise stated in a credit line to the data. 


\section{Background}

The Holy pilgrimage to Mecca, Saudi Arabia is one of the five cardinal pillars of worship upon every financially and physically able Muslim individual. Hajj is among the largest mass gathering in the world, with approximately 2 million pilgrims participating from different countries every year [1]. This poses a great risk to public health considering the overcrowding, presence of comorbidities among the pilgrims and adverse climatic condition are huge challenges to both participating and the host countries especially regarding infectious diseases such as respiratory tract infections [2]. On the other hand, Umrah also known as Lesser Hajj can be performed at any time of the year and is not obligatory on Muslims; however, is a highly significant religious practice [3].

Respiratory tract infections are the most prevalent illnesses spread throughout the Hajj period, and influenza virus and rhinovirus are the most commonly reported respiratory viruses among pilgrims [4]. However, a high prevalence of respiratory tract illnesses is still reported among Malaysian Hajj pilgrims at over 90\% despite the implementation of different preventive measures over recent years [5].

The current pandemic due to the novel severe acute respiratory syndrome coronavirus 2 (SARS-CoV-2) which was first reported in Hubei province of China in December 2019 has prompted many researchers with the development of a valid and reliable tool for the measurement its knowledge, attitude and practice (KAP) among various communities [6]. The World Health Organization (WHO) declared the infection as a pandemic in March 2020 [7] with more than 9 million confirmed cases and 469,239 deaths due to of Covid-19 from 188 countries across the world based on the figures from the Johns Hopkins University Coronavirus resource centre [8]. Similarly, Saudi Arabia, being the sole host of the Hajj and Umrah pilgrimage, has recorded 161,005 confirmed cases of COVID-19 resulting in more than 1300 deaths [8]. This has prompted Saudi Arabia authorities to initiate more proactive protective precautions such as temporary suspension of Umrah pilgrimage and limiting Hajj 2020 pilgrimage to only a few Saudi residents with strict guidelines on the rules of social distancing, the use of face mask and proper hand hygiene [9-11].

Confirmatory factor analysis (CFA) is advance construct validity and superior to exploratory factor analysis (EFA) and simple reliability analysis (test-retest and internal consistency reliabilities) in several ways. CFA is also a kind of structural equation modelling (SEM) that is related to measurement models [12]. The application of CFA is worthwhile to support the links connecting items and their respective domains. This permits the fixing of these relations in the measurement model and presents measures to evaluate the fit of the proposed theoretical model to the collected data [13]. Therefore, CFA is regarded as a vital means for validation in the social and behavioural sciences [12]. Measurement scale development involves numerous processes and protocols to establish its validity and reliability. The content and characteristics of the basic constructs and the choice of items to be included can also be established in a pilot study or adopted from a previous similar study and validated by CFA [14]. The application of improper measurement tools that are not validated can lead to inaccurate and misleading findings, resulting in a poor plan for interventions and therefore, too unreliable efficacy [15]. The Item Response Theory models (Rasch model) utilizes the principle of true Score models which comprises a collection of dogmatic formulae for systematic analysis to achieve the desired objective [16].

So far, few studies specifically reported the knowledge, attitude and practice of various respiratory tract infections preventive behaviours by Hajj pilgrims [17-23], however, none of these studies were documented to have employed a questionnaire that is properly developed and validated. Therefore, this study was aimed at determining the construct validity and reliability of the knowledge, attitude and practice (KAP) questionnaire towards the prevention of respiratory tract infections during Hajj and Umrah among Malaysian Hajj pilgrims.

\section{Methods}

\section{Research design and study population}

A cross-sectional study was carried out among Malaysian Umrah pilgrims attending a weekly Umrah orientation course organized by private Umrah tour companies from March to June 2018. This study was the second stage of a large study [24-26]. In the first stage, we conducted an exploratory factor analysis of the measurement tool [24].

\section{Sample size and sampling method}

A total of 200 Umrah pilgrims were recruited through a multistage sampling method for the 72 items in the KAP questionnaire for prevention of respiratory tract infection (RTI) during Hajj. The sample size for this study was based on a simulation study, as recommended by Hair et al. (2010) [27] for CFA. Therefore the sample size for this study was fixed at $n=200$ when the anticipated domains were seven or less, and items commonality was less than 0.5 and no under identified domains.

The sampling method used was done in two stages. The first stage was a purposive selection of private Hajj and Umrah companies as clusters. Hajj/Umrah travel companies were eligible if: 1) they were located in Kota Bharu, Kelantan; 2) they conduct weekly Hajj/Umrah orientation courses, and if; 3) the management was willing to participate actively in the study and to collaborate with the researcher from Universiti Sains Malaysia. Five Hajj/Umrah tour companies were identified and contacted about the project, and only two companies agreed to participate. 
The participants were approached during the routine orientation courses conducted by the Hajj/Umrah travel companies for the pilgrims after being briefed about the validation study and seeking consent from them by research assistants in Malay language by three (3) research assistants. The questionnaires were distributed to the pilgrims at the beginning of the course and collected back at the end of the day's session. Incentives were provided to the participants.

\section{Measurement tool}

A self-administered questionnaire for the measurement of pilgrim's KAP towards the prevention of RTIs as used in a previous study [24] was used in this study. All the domains, as well as the sub-domains, have been developed and exploratory factor analysis (EFA) was done [24].

\section{Data collection procedures}

All data were collected from June 2018 to August 2018. A self-administered questionnaires were distributed to the Umrah pilgrims before their weekly course that met the inclusion criteria. Pilgrims that are aged 18 years and above, able to write and speak in Bahasa Malay and are willing to participate are considered to have fulfilled the inclusion criteria. Participants were briefed on the purpose of the study, the procedures, and the confidentiality of their responses. Informed consent was obtained from the participants that are willing to be part of the study prior to the administration of the questionnaire. The pilgrims were also instructed to give their honest responses when answering the questionnaire. The completed questionnaire was immediately retrieved from the participants at the end of the day's orientation. The time to complete the questionnaire was approximately 10 to $15 \mathrm{~min}$.

\section{Data management and preliminary analysis}

All data were entered and checked for missing data using SPSS software version 24 and then transferred to $\mathrm{R}$ version 3.5.0 for Item Response Theory (IRT) and Confirmatory factor analysis (CFA) analysis. Data analysis was done using $R$ version 3.5.0 in the $R$ Studio environment.

\section{Item response theory (IRT)}

Considering the dichotomous outcome of the responses of the items in the knowledge section, two-parameter logistic item response theory (2-PL IRT) analysis was done using the ltm package version 1.0.0 6.

\section{Confirmatory factor analysis (CFA)}

Confirmatory factor analysis (CFA) was conducted to confirm the factorial structure of the KAP questionnaire identified in the EFA published in the other part of this study. The attitude and practice domains were analysed as recommended by lavaan package version $0.5-22$ [28]. Several indices indicated a good model fit for the construct, they include: the ratio of chi-square to degree of freedom $\left(\chi^{2} / \mathrm{df}\right)<5.0$, root mean square error of approximation (RMSEA) $\leq 0.08$, comparative fit index (CFI) $>0.9$, Tucker Lewis Index (TLI) $>0.9$, and $p>0.05$ for the chi-square test [29]. For composite reliability, semTools package version $0.4-14 \quad 5-6$ was used to determine the Raykov's rho $[29,30]$. Hair et al. [27] suggested that model fitness can be decided by at least a minimum of three different indices. A good relationship between items and respective factors are shown by a standardized factor loading greater than 0.5 as well as a $p$-value of less than 0.05 and it therefore further proves the validity of the construct. Composite reliability of the domains was calculated with a value of 0.7 and above was considered acceptable [27, 31].

\section{Results}

A total of 200 Umrah pilgrims responded to this study. On data screening, no missing data was found. The age of the participants from this study ranged from 18 to 80 years old with, a mean age of 39.13 (SD 16.03). The females (65.5\%) dominated the number of pilgrims. The socio-demographic characteristics of the participants are shown in Table 1.

In the knowledge section, IRT analysis results showed an acceptable range for both difficulty ( -3 to $+3)$ and the discrimination parameter on each of the items in all the sub domains. The sub-domains are SD1 (K1i, K1ii, K1iii), SD2 (K2i, K2ii, K2iii, K2iv, K2v, K3), SD3 (K4i, K4ii, K4iii, K4iv, K4v and K4vi), SD4 (K5i, K5ii, K5iii, K5iv and K5v), prevention practices (K6i, K6ii, K6iii, K6iv and K6v) and SD5 (K7i, K7ii, K7iii, K8 and K9) covering the aetiology, transmission, risk factors, complications, preventive practices and the use of personal protective equipment (PPE). However, all the items were retained because they had acceptable difficulty and discrimination values. The amount of information tapped by the items between -3 and +3 difficulty range was $93.1 \%$. The unidimensionality assumption was not supported by the modified parallel test at $\alpha=0.05(p=0.010)$. In terms of internal consistency reliability, Cronbach's alpha was 0.9. IRT analysis for the psychometric characteristics of the domain, as shown in Table 2.

For the attitude domain, the two-factor model was then tested by CFA using an MLR estimation method. MLR was used because the data did not follow a multivariate normal distribution required by the MLR. 
Table 1 Socio-demographic characteristics of participants $(n=$ 200)

\begin{tabular}{|c|c|c|}
\hline Variables & Mean (SD) & Frequency (\%) \\
\hline Age (years) & $39.13(16.029)$ & \\
\hline \multicolumn{3}{|l|}{ Gender } \\
\hline Male & & $65(35.5)$ \\
\hline Female & & $131(65.5)$ \\
\hline \multicolumn{3}{|l|}{ Ethnicity } \\
\hline Malay & & $197(98.5)$ \\
\hline Indian & & $1(0.5)$ \\
\hline Others & & $2(1.0)$ \\
\hline \multicolumn{3}{|l|}{ Marital status } \\
\hline Single & & $89(44.5)$ \\
\hline Married & & $109(54.5)$ \\
\hline Divorced/widowed & & $2(1.0)$ \\
\hline \multicolumn{3}{|l|}{ Occupation } \\
\hline Student & & $19(9.5)$ \\
\hline Civil servant & & $37(18.5)$ \\
\hline Private sector & & $95(47.5)$ \\
\hline Pensioner & & $22(11)$ \\
\hline Housewife & & $15(7.5)$ \\
\hline Self-employed & & $12(6)$ \\
\hline \multicolumn{3}{|l|}{ Highest level of education } \\
\hline $\mathrm{PhD}$ & & $4(2.0)$ \\
\hline Master's degree & & $13(6.5)$ \\
\hline Bachelor's degree & & $42(21.0)$ \\
\hline Diploma & & $73(36.5)$ \\
\hline Secondary school & & $54(27.0)$ \\
\hline Primary school & & $14(7.0)$ \\
\hline \multicolumn{3}{|l|}{ History of vaccination } \\
\hline Meningococcal vaccine & & $60(30)$ \\
\hline Influenza (flu) vaccine & & $29(14.5)$ \\
\hline Pneumococcal vaccine & & $24(12.0)$ \\
\hline \multicolumn{3}{|l|}{ Presence of Co-morbidities } \\
\hline Chronic lung disease & & $1(0.5)$ \\
\hline Neuromuscular disease & & $9(4.5)$ \\
\hline Allergic rhinitis & & $2(1.0)$ \\
\hline Diabetes & & $6(3.0)$ \\
\hline Hypertension & & $29(14.5)$ \\
\hline Heart disease & & $2(1.0)$ \\
\hline Chronic kidney disease & & $2(2)$ \\
\hline Immune deficiency disorders & & $1(0.5)$ \\
\hline
\end{tabular}

Satisfactory model fitness was not demonstrated by the initial 12-item factor. To achieve the model fitness, the maximum likelihood (ML) values were examined and re-analysed to achieve a better model fit. To be included in the model, items with high correlated errors within the same factor will be considered. The two-factor model showed a good fit $\left(x^{2}\right.$ $[\mathrm{df}=6]=43, \quad p<0.001 ; \quad C F I_{\text {robust }}=0.928 ; \quad \mathrm{TLI}_{\text {robust }}=$ 0.890; RMSEA $_{\text {robust }}=0.063 ;$ SRMR $\left.=0.079\right)$ as shown in Table after correlated errors (A12A $\leftrightarrow \mathrm{A} 13, \quad r=$ $0.341 ; \quad \mathrm{A} 3 \leftrightarrow \mathrm{A} 9, \quad r=-0.267 ; \quad \mathrm{A} 5 \mathrm{~A} \leftrightarrow \mathrm{A} 5 \mathrm{~B}, \quad r=0.265 ;$ $\mathrm{A} 8 \leftrightarrow \mathrm{A} 7, r=0.268 ; \mathrm{A} 8 \leftrightarrow \mathrm{A} 9, r=0.240 ; \mathrm{A} 10 \leftrightarrow \mathrm{A} 4, r=$ $-0.237 ; \mathrm{A} 10 \leftrightarrow \mathrm{A} 7, \quad r=-0.191 ; \mathrm{A} 3 \leftrightarrow \mathrm{A} 5 \mathrm{~B}, \quad r=0.267$; $\mathrm{A} 9 \leftrightarrow \mathrm{A} 5 \mathrm{~B}, \quad r=-0.168 ; \quad \mathrm{A} 10 \leftrightarrow \mathrm{A} 5 \mathrm{~B}, \quad r=0.205)$ were added. However, the two sub-domains under attitude (barriers to compliance and self-motivation) have a correlation between them of $r=0.444$. The composite reliability of the barriers to compliance and selfmotivation factor all have a satisfactory cut-off value of $>0.7$ as summarize in Table 3 .

For practice domain which comprises of 13 items, the two-factor model was analyzed by CFA. The model showed an acceptable fitness, as shown in Table $4\left(x^{2}\right.$ $[\mathrm{df}=64]=31.49, \quad p<0.001 ; \quad$ CFIrobust $=0.903 ; \quad$ TLIrobust $=0.882$; RMSEArobust $=0.073$; SRMR $=0.067$ ). The correlations between the factors were: Healthylifestyle $\leftrightarrow$ Prevention-practices $(r=0.471)$. The composite reliability of the healthy lifestyle and prevention practices factors were above the cut-off value of 0.7 (Raykov's rho $=0.863$ and 0.827 ), despite the low standardized loading for item P7.

The model showed an acceptable fitness for both attitude and practice. In the attitude domain, two-factor model showed a good fit $\left(\mathrm{X}^{2}[\mathrm{df}=6]=43, p<0.001\right.$; $\mathrm{CFI}_{\mathrm{ro}}$ bust $=0.928 ; \quad \mathrm{TLI}_{\text {robust }}=0.890 ; \quad \mathrm{RMSEA}_{\text {robust }}=0.063$; SRMR $=0.079)$ after correlated errors $(\mathrm{A} 12 \mathrm{~A} \leftrightarrow \mathrm{A} 13, r=$ $0.341 ; \quad \mathrm{A} 3 \leftrightarrow \mathrm{A} 9, \quad r=-0.267 ; \quad \mathrm{A} 5 \mathrm{~A} \leftrightarrow \mathrm{A} 5 \mathrm{~B}, \quad r=0.265 ;$ $\mathrm{A} 8 \leftrightarrow \mathrm{A} 7, r=0.268 ; \mathrm{A} 8 \leftrightarrow \mathrm{A} 9, r=0.240 ; \mathrm{A} 10 \leftrightarrow \mathrm{A} 4, r=$ $-0.237 ; \quad \mathrm{A} 10 \leftrightarrow \mathrm{A} 7, \quad r=-0.191 ; \mathrm{A} 3 \leftrightarrow \mathrm{A} 5 \mathrm{~B}, \quad r=0.267 ;$ $\mathrm{A} 9 \leftrightarrow \mathrm{A} 5 \mathrm{~B}, \quad r=-0.168 ; \quad \mathrm{A} 10 \leftrightarrow \mathrm{A} 5 \mathrm{~B}, \quad r=0.205) \quad$ were added. For the practice domain, the fitness indices $\left(\chi^{2}\right.$ $[\mathrm{df}=64]=31.49, \quad p<0.001 ; \quad$ CFIrobust $=0.903$; TLIrobust $=0.882$; RMSEArobust $=0.073$; SRMR $=0.067$ ) are well represented. The fitness indices are summarized in Table 5.

\section{Discussion}

This study validated a Malay questionnaire for the KAP evaluation of Hajj pilgrims towards the prevention of respiratory tract infections. Overall, the results of the CFA for all the domains indicated that the measurement models for each construct are fit except the attitude domain that undergone through a model modification to improve the model fit. Finding from this study could not be compared with the psychometric properties from other studies conducted on the knowledge, attitudes and practices on respiratory tract infection due to the paucity of documented and 
Table 2 Result of the IRT analysis in the knowledge section $(n=200)$

\begin{tabular}{|c|c|c|c|c|c|}
\hline Items & $b$ & $a$ & $\lambda$ & $X^{2}(d f=8)$ & $P$ values \\
\hline \multicolumn{6}{|l|}{1 Flu-like illnesses are caused by: } \\
\hline i Allergies & -0.41 & 3.50 & 0.9 & 100.55 & $<0.001$ \\
\hline ii Bacteria & -0.54 & 2.16 & 0.78 & 62.98 & $<0.001$ \\
\hline iii Virus & -1.04 & 3.12 & 0.87 & 120.2 & $<0.001$ \\
\hline \multicolumn{6}{|l|}{2 Flu-like illnesses are spread by: } \\
\hline i Air & -1.10 & 3.39 & 0.88 & 24.34 & 0.002 \\
\hline ii Dust & -0.86 & 2.24 & 0.79 & 26.19 & 0.001 \\
\hline iii Sharing towels with an infected person & -0.32 & 3.95 & 0.94 & 52.78 & $<0.001$ \\
\hline iv Water & 0.24 & 2.32 & 0.82 & 88.76 & $<0.001$ \\
\hline$\checkmark$ Shaking the hands of an infected person with a cough and/or cold & -0.16 & 1.90 & 0.75 & 52.42 & $<0.001$ \\
\hline 3 Flu-like illnesses are spread quickly & -1.17 & 1.41 & 0.64 & 101.32 & $<0.001$ \\
\hline \multicolumn{6}{|l|}{4 The following persons are at an increased risk of flu-like illnesses: } \\
\hline i Asthmatics & -0.87 & 2.83 & 0.86 & 43.63 & $<0.001$ \\
\hline ii Diabetics & 0.40 & 4.32 & 0.93 & 21.16 & 0.007 \\
\hline iii People with arthritis & 0.43 & 2.34 & 0.80 & 50.84 & $<0.001$ \\
\hline iv Senior citizens aged 65 and older & -0.57 & 1.94 & 0.75 & 29.26 & $<0.001$ \\
\hline$\vee$ Smokers & -0.14 & 3.08 & 0.87 & 75.46 & $<0.001$ \\
\hline vi Those in crowded places/among a lot of people & -1.13 & 1.83 & 0.73 & 49.71 & $<0.001$ \\
\hline \multicolumn{6}{|l|}{5 What are the complications of flu-like illnesses? } \\
\hline i Bronchitis & -0.14 & 2.93 & 0.91 & 126.49 & $<0.001$ \\
\hline ii Difficulty in breathing & 0.64 & 6.26 & 0.88 & 22.80 & 0.004 \\
\hline iii Multi-organ failure & 0.55 & 2.85 & 0.89 & 170.57 & $<0.001$ \\
\hline iv Pneumonia & -0.27 & 2.76 & 0.90 & 91.12 & $<0.001$ \\
\hline \multicolumn{6}{|l|}{6 The following practices can help protect you from flu-like illnesses: } \\
\hline i Covering your nose with your hands & -0.67 & 1.75 & 0.92 & 71.99 & $<0.001$ \\
\hline ii Ensuring a healthy diet & -1.05 & 2.29 & 0.50 & 38.14 & $<0.001$ \\
\hline ii Receiving vaccinations & -0.80 & 2.26 & 0.85 & 66.51 & $<0.001$ \\
\hline iv Washing your hands with hand sanitizers & -0.86 & 6.29 & 0.78 & 15.08 & $<0.001$ \\
\hline$\checkmark$ Wearing a face mask & -1.22 & 5.07 & 0.71 & 10.75 & $<0.001$ \\
\hline \multicolumn{6}{|l|}{7 The following are reasons for wearing a mask: } \\
\hline i Being in crowded places & -1.03 & 6.11 & 0.97 & 11.82 & $<0.001$ \\
\hline ii Being near people who are coughing & -1.26 & 4.83 & 0.96 & 20.75 & 0.008 \\
\hline iii When I am sick & -0.91 & 4.33 & 0.94 & 49.03 & $<0.001$ \\
\hline 8 A cloth facial mask is as effective as a 2-ply surgical facial mask & 1.02 & 1.29 & 0.60 & 60.85 & $<0.001$ \\
\hline 9 If I am not sick, the used face mask can be stored in a bag for later use & 0.72 & 1.56 & 0.67 & 182.10 & $<0.001$ \\
\hline
\end{tabular}

described the validation process. Our findings support the originally developed two-factor sub-domain for each of the attitude and practice.

Based on the assumptions checking for multivariate, the data were not normally distributed for CFA. Therefore, MLR was the preferred method for fitting the CFA model to turn over the violation of the normality of the multivariate analysis. Due to the aforementioned reason, estimation of MLR was done using robust (Huber-White) with standard errors and a scaled test statistic that is hypothetically matched the Yuan-Bentler test statistic [31-33].

Our findings showed a reasonably good fit for the questionnaire, giving confirmatory details for the factor structure for both domains. All the fit indices (RMSEA, CFI, TLI, SRMR) are within acceptable values and therefore supported the construct validity [34]. There are numerous studies done in Malaysia 
Table 3 Results of CFA of the attitude section

\begin{tabular}{|c|c|c|c|}
\hline Factors & Items & $\begin{array}{l}\text { Factor } \\
\text { loading }\end{array}$ & $\begin{array}{l}\text { Reliability } \\
\text { (Raykov's rho) }\end{array}$ \\
\hline \multirow[t]{5}{*}{$\begin{array}{l}\text { Barriers to } \\
\text { compliance }\end{array}$} & $\begin{array}{l}\text { A3: Since the bird flu, SARS, MERS-COV and H1N1 crises are over, I no longer need to worry } \\
\text { about contracting flu-like illnesses }\end{array}$ & 0.696 & 0.76 \\
\hline & A8: I am generally opposed to wearing a face mask & 0.555 & \\
\hline & A9: Flu vaccinations have unpleasant side effects & 0.376 & \\
\hline & A10: I am influence by negative news about flu vaccines & 0.751 & \\
\hline & A11: It is too much trouble to get a flu vaccine & 0.751 & \\
\hline \multirow[t]{8}{*}{ Self-motivation } & A4 If I have a flu-like illness, I may spread it to others & 0.516 & 0.72 \\
\hline & A5: I feel that someone that have influenza-like illness should: & & \\
\hline & A5A: cover his mouth and nose with his bare hand when coughing or sneezing & 0.603 & \\
\hline & A5B: cover his mouth and nose with a handkerchief when coughing or sneezing & 0.402 & \\
\hline & A6: Influenza vaccines protects hajj pilgrims from influenza & 0.75 & \\
\hline & A7: Using a hand wash can prevent you from getting flu like illness & 0.652 & \\
\hline & A12A: I think coughs and the flu can be prevented by wearing a mask outside my house & 0.424 & \\
\hline & A13: Wearing a well-fitting face mask is effective in preventing flu-like illnesses & 0.431 & \\
\hline
\end{tabular}

which support the accepted values of the fit indices, which is similar to the present study results [35-37].

The reliability of the various domains was based on the Raykov's rho which accounts for what of each individual item stands for and its latent error; however, they provide much less biased estimate of Cronbach's alpha. The attitude and practice factors of the KAP questionnaire had good reliability, as shown by the reliability coefficients exceeding 0.70 .

In this study, like much other research, has some limitations. Firstly, data were collected from Umrah pilgrims using a sampling that is non-random in nature and thus should not necessarily be considered representative of the population and may not be a similar experience to Hajj pilgrimage. Secondly, majority of the participants are of Malay race, future research should incorporate other race to make it heterogenous population. Finally, as stated earlier, this is the first study on confirmatory factor analysis of KAP on respiratory tract infection prevention in Malaysia and therefore comparison to other studies is not possible.

Table 4 Results of CFA of the practice domain

\begin{tabular}{llll}
\hline Factors & Items & Factor loading & Reliability (Raykov's rho) \\
\hline Health lifestyle & P1: I eat vegetables & 0.918 \\
& P2: I eat fruits & 0.888 \\
& P5: I use soap to wash my hands & 0.664 \\
Prevention practices & P4: When wearing a mask, I test it to ensure it fits properly & 0.535 \\
& P6: I use disinfectant or disposable wipes or hand gel to wash my hands & 0.483 \\
& P7: I use a washable cloth handkerchief to clean my hands & 0.284 \\
& P8: I wash my hands after: & \\
P8A: touching the personal items of someone who has a cough and/or cold & 0.744 \\
P8B: shaking hands with people who have a cough and/or cold & 0.787 \\
P8C: touching doorknobs & 0.692 \\
P9: I refrain from: & \\
P9A: being close to those who cough or sneeze & 0.562 \\
P9B: shaking the hands of those who have a cough and/or cold & 0.577 \\
P9C: often touching my nose & 0.365 \\
P10: I received the flu vaccine & 0.511 \\
\hline
\end{tabular}


Table 5 Fit Indices for Confirmatory Factor Models

\begin{tabular}{llllllllll}
\hline Factors & $\begin{array}{l}\text { No } \\
\text { of } \\
\text { items }\end{array}$ & $\boldsymbol{X}^{\mathbf{2}}$ (df) & P value & & df & CFI & TLI & RMSEA & SRMR \\
\hline Attitude & 12 & $76.8(43)$ & $<0.001$ & 66 & 0.928 & 0.890 & 0.063 & 0.079 \\
Practice & 13 & $121(76)$ & $<0.001$ & 64 & 0.903 & 0.882 & 0.073 & 0.067 \\
\hline
\end{tabular}

\section{Conclusions}

The KAP questionnaire has shown to have good validity, reliability and psychometric properties towards measuring knowledge, attitude and practice of Malaysian Hajj pilgrims towards prevention of respiratory tract infection. This article could serve as a template for the implementation of various studies in community settings amidst the current Covid19 pandemic for effective prevention and control strategies.

\section{Abbreviations}

RTI: Respiratory tract infection; IRT: Item response theory; CFA: Confirmatory factor analysis; KAP: Knowledge, attitude, and practice

\section{Acknowledgements}

We would like to thank the Management and staff of Andalusia Travel and Al Quds Umrah \& Tours Sdn Bhd for the collaboration as well as all the participants in this study.

\section{Authors' contributions}

MDG, NNN and HH designed the research, developed the questionnaire, collected the data, and performed the statistical analysis; $\mathrm{NNN}, \mathrm{HH}$, WNA and $A A B$ participated in the design, the development of the questionnaire, and the data collection and data analysis and critically reviewed the work and this report; and NWA, ZZD, and SN participated in the design and critically reviewed the statistical analysis and the work of this report. All authors read and approved the final manuscript.

\section{Funding}

This study was funded by the Universiti Sultan Zainal Abidin Special Research Grant Scheme 2017 (UniSZA/2017/SRGS/16) and Keputusan Permohonan Tabung Insentif Pembangunan Penganjian Siswazah PPSP (TIPP S) 2017. We would like to acknowledge the USM Global Fellowship awarded to the first author. The funding bodies had no role in the design of the study, data collection, analysis and interpretation of data, and writing of the manuscript.

\section{Availability of data and materials}

The datasets used and/or analysed during the current study are available from the corresponding author on reasonable request.

\section{Ethics approval and consent to participate}

Ethical approvals were obtained from the Human Research Ethics Committee of Universiti Sains Malaysia [ref no: USM/JEPeM/17020146]. The questionnaire was designed to be anonymous, and informed written consent was obtained from every respondent. The data were kept confidential and the results would not identify the respondents personally.

\section{Consent for publication}

Not applicable.

\section{Competing interests}

The authors declare that they have no competing interest.

\section{Author details}

'Ministry of Agriculture and Natural Resources, IBB Secretariat Complex, Yobe State Government, Damaturu, Nigeria. ${ }^{2}$ Faculty of Medicine, Medical Campus Universiti Sultan Zainal Abidin, 20400 Kuala Terengganu, Malaysia.

${ }^{3}$ Department of Microbiology and Parasitology, School of Medical Sciences,
Universiti Sains Malaysia, 16150 Kubang Kerian, Kelantan, Malaysia. ${ }^{4}$ Faculty of Health Sciences, Gong Badak Campus, Universiti Sultan Zainal Abidin, 21300 Kuala Nerus, Terengganu, Malaysia. ${ }^{5}$ Unit of Biostatistics and Research Methodology, School of Medical Sciences, Universiti Sains Malaysia Health Campus, 16150 Kubang Kerian, Kelantan, Malaysia. ${ }^{6}$ Centre for Language Studies and Generic Development, Universiti Malaysia Kelantan, Locked Bag 01, 16300 Bachok, Kelantan, Malaysia. 'Department of Nursing Science, School of Health Sciences, Universiti Sains Malaysia Health Campus, 16150 Kubang Kerian, Malaysia.

Received: 19 March 2020 Accepted: 23 October 2020

Published online: 10 November 2020

\section{References}

1. Shirah BH, Zafar SH, Alferaidi OA, Sabir AMM. Mass gathering medicine (hajj pilgrimage in Saudi Arabia): the clinical pattern of pneumonia among pilgrims during hajj. J Infect Public Health. 2017;10(3):277-86.

2. Memish ZA, Zumla A, Alhakeem RF, Assiri A, Turkestani A, Al Harby KD, et al. Hajj: infectious disease surveillance and control. Lancet. 2014;383(9934): 2073-82.

3. Yezli S, Yassin Y, Awam A, Attar A, Al-Jahdali E, Alotaibi B. Umrah. An opportunity for mass gatherings health research. Saudi Med J. 2017;38(8): 868-71.

4. Gautret P, Benkouiten S, Al-Tawfiq JA, Memish ZA. Haij-associated viral respiratory infections: a systematic review. Travel Med Infect Dis. 2016;14(2): 92-109.

5. Hashim S, Ayub ZN, Mohamed Z, Hasan H, Harun A, Ismail N, et al. The prevalence and preventive measures of the respiratory illness among Malaysian pilgrims in 2013 Hajj season. J Travel Med. 2016;23(2):tav019.

6. Zhu H, Wei L, Niu P. The novel coronavirus outbreak in Wuhan, China. Glob Health Res Policy. 2020;5:6

7. Organization WH. Coronavirus disease 2019 (COVID-19): situation report, 72. 2020.

8. John Hopkins University Corona Virus Resource Center. Coronavirus COVID19 Global Cases by the Center for Systems Science and Engineering (CSSE) 2020 [Available from: https://coronavirus.jhu.edu/map.html. Accessed 12 Apr 2020

9. Arab News. Saudi Arabia: Hajj 2020 to be held with limited number of pilgrims 2020 [Available from: https:/www.arabnews.com/node/1693856/ saudi-arabia. Accessed 23 June 2020.

10. Ahmed QA, Memish ZA. The cancellation of mass gatherings (MGs)? Decision making in the time of COVID-19. Travel Med Infect Dis. 2020; 101631.

11. Ebrahim SH, Memish ZA. Saudi Arabia's drastic measures to curb the COVID19 outbreak: temporary suspension of the Umrah pilgrimage. J Travel Med. 2020;27(3):taaa029.

12. Brown TA. Confirmatory factor analysis for applied research. New York: Guilford Publications; 2014

13. Stevens JP. Applied multivariate statistics for the social sciences. University of Cincinati, USA: Routledge; 2012.

14. Alumran A, Hou X-Y, Hurst C. Validity and reliability of instruments designed to measure factors influencing the overuse of antibiotics. I Infect Public Health. 2012;5(3):221-32

15. Hewlett $\mathrm{S}$, Hehir M, Kirwan JR. Measuring fatigue in rheumatoid arthritis: a systematic review of scales in use. Arthritis Care Res. 2007:57(3):429-39.

16. Mohamad MM, Sulaiman NL, Sern LC, Salleh KM. Measuring the validity and reliability of research instruments. Procedia Soc Behav Sci. 2015;204:164-71.

17. Alhomoud F, Alhomoud F, Editors. Hajj pilgrims' knowledge, attitude and practices regarding Middle East respiratory syndrome coronavirus (MERSCoV). International journal of clinical pharmacy; 2017; Chicago: SPRINGER VAN GODEWIJCKSTRAAT 30, 3311 GZ DORDRECHT, NETHERLANDS.

18. Alqahtani AS, Wiley KE, Mushta SM, Yamazaki K, BinDhim NF, Heywood AE, et al. Association between Australian Hajj Pilgrims' awareness of MERS-CoV, and their compliance with preventive measures and exposure to camels. J Travel Med. 2016;23(5):1-5.

19. Gautret P, Benkouiten S, Salaheddine I, Belhouchat K, Drali T, Parola P, et al. Hajj pilgrims' knowledge about Middle East respiratory syndrome coronavirus, august to September 2013. Eurosurveillance. 2013;18(41):20604.

20. Sahin MK, Aker S, Tuncel EK. Knowledge, attitudes and practices concerning Middle East respiratory syndrome among Umrah and hajj pilgrims in Samsun, Turkey, 2015. Eurosurveillance. 2015;20(38):30023. 
21. Dumyati MS, Bakr Balubaid SA, Althobaiti FA, Azizurrehman HA, Sindi BZ. Knowledge, Attitude and Practices About Pneumococcal Infection among Algerian Hajj Pilgrims. Egyptian J Hospital Med. 2018;70(5):806-17.

22. Sridhar S, Belhouchat K, Drali T, Benkouiten S, Parola P, Brouqui P, et al. French hajj pilgrims' experience with pneumococcal infection and vaccination: a knowledge, attitudes and practice (KAP) evaluation. Travel Med Infect Dis. 2015;13(3):251-5.

23. Alqahtani AS, Wiley KE, Tashani M, Willaby HW, Heywood AE, BinDhim NF, et al. Exploring barriers to and facilitators of preventive measures against infectious diseases among Australian hajj pilgrims: cross-sectional studies before and after hajj. Int J Infect Dis. 2016:47:53-9.

24. Goni MD, Naing NN, Hasan H, Wan-Arfah N, Deris ZZ, Arifin WN, et al. Development and validation of knowledge, attitude and practice questionnaire for prevention of respiratory tract infections among Malaysian haij pilgrims. BMC Public Health. 2020;20(1):1-10.

25. Goni MD, Hasan H, Naing NN, Wan-Arfah N, Deris ZZ, Arifin WN, et al. Assessment of knowledge, attitude and practice towards prevention of respiratory tract infections among hajj and Umrah pilgrims from Malaysia in 2018. Int J Environ Res Public Health. 2019;16(22):4569.

26. Goni MD, Naing NN, Hasan H, Arfah NW, Arifin WN, Baaba AA. Uptake of recommended vaccines and its associated factors among Malaysian pilgrims during hajj and Umrah 2018. Front Public Health. 2019;7:268.

27. Hair JF, Black WC, Babin BJ, Anderson RE. Multivariate Data Analysis: A Global Perspective. 7th Edition, Pearson Education: Upper Saddle River; 2010.

28. Rosseel Y. Lavaan: an R package for structural equation modeling and more. Version 0.5-12 (BETA). J Stat Softw. 2012;48(2):1-36.

29. Hou D, Al-Tabbaa A, Chen H, Mamic I. Factor analysis and structural equation modelling of sustainable behaviour in contaminated land remediation. J Clean Prod. 2014;84:439-49.

30. Hassim SR, Arifin WN, Kueh YC, Yaacob NA. Confirmatory factor analysis of the Malay version of the smartphone addiction scale among medical students in Malaysia. Int J Environ Res Public Health. 2020;17(11):3820,

31. Raykov T, Marcoulides GA. Scale reliability evaluation under multiple assumption violations. Struct Equ Model Multidiscip J. 2016;23(2):302-13.

32. Geldhof GJ, Preacher K, Zyphur MJ. Reliability estimation in a multilevel confirmatory factor analysis framework. Psychol Methods. 2014:19(1):72.

33. Beaujean AA. Latent variable modeling using R: a step-by-step guide. New York: Routledge; 2014

34. Perry JL, Clough PJ, Crust L, Earle K, Nicholls AR. Factorial validity of the mental toughness questionnaire-48. Personal Individ Differ. 2013;54(5):587-92.

35. Zahiruddin WM, Arifin WN, Mohd-Nazri S, Sukeri S, Zawaha I, Bakar RA, et al. Development and validation of a new knowledge, attitude, belief and practice questionnaire on leptospirosis in Malaysia. BMC Public Health. 2018;18(1):331.

36. Abdullah M, Azib W, Harun M, Burhanuddin M. Reliability and construct validity of knowledge, attitude and practice on dengue fever prevention questionnaire. Am Int J Contemp Res. 2013;3:69-75.

37. Hiew C, Chin Y, Chan Y, Mohd N. Development and validation of knowledge, attitude and practice on healthy lifestyle questionnaire (KAPHLQ) for Malaysian adolescents. J Nutri Health Sci. 2015;2(4):1-11.

\section{Publisher's Note}

Springer Nature remains neutral with regard to jurisdictional claims in published maps and institutional affiliations.

Ready to submit your research? Choose BMC and benefit from:
- fast, convenient online submission
- thorough peer review by experienced researchers in your field
- rapid publication on acceptance
- support for research data, including large and complex data types
- gold Open Access which fosters wider collaboration and increased citations
- maximum visibility for your research: over 100M website views per year
At BMC, research is always in progress.
Learn more biomedcentral.com/submissions

